\title{
Spurious Coin: A History of Science, Management and Technical Writing
}

\author{
By Catherine F. Schryer \\ University of Waterloo
}

\begin{abstract}
Bernadette Longo. Spurious Coin: A History of Science, Management and Technical Writing, Albany, NY: State University of New York Press, 2000.
\end{abstract}

In a recent exchange on Cattw-net, Suzanne Townsend, Rob Irish, Peter Weis, and Shurli Makmillen debated the role of technical communicators in workplaces. Townsend initiated the debate by challenging members of CATTW to explain their role in preparing students for positions in technical communication. From her perspective, software and engineering companies require technical writers because "developers or creators are too close to their subject matter to be able to write about it clearly." She observed that it was only "common sense" for organizations to hire technical communicators because engineers are not great at communication, and companies hire engineers not to write their documentation but to develop and create products. The other interlocutors disagreed with Townsend. Both Irish and Weis outlined their position that engineers needed to be effective communicators, and Makmillen quoted her brother (an engineer) who asserted that "whoever writes technical literature must be both technical and literate".

These interlocutors would find Bernadette Longo's Spurious Coin: A History of Science, Management and Technical Writing illuminating. In her cultural history Longo provides the background to this debate and an extensive genealogy for the field of technical communication as practiced in the United States. Longo insists, in fact, that the division between engineers and other subject matter experts (SME) is not "common sense," but the result of social and historical forces that extend far beyond the narrow confines of technical communication.

Her history begins in the present with the (at least to me) astonishing claims that technical writing "continued throughout this century to stabilize our culture's system of knowledge and power based on scientific knowledge" (P.1) and that "technical writing is the control mechanism of scientific and technical knowledge production" 
(p.2). Longo then provides an analysis of several current research studies noting that most studies provide only descriptive accounts of technical communication practices and fail to note how technical communication practices are connected to socially situated institutional relationships of knowledge and power. In fact, technical communication practices seem remarkably "invisible" within organizations. Her study, using Foucault as a model, intends to provide a systematic history of technical communication as a discourse so as to make technical communication more visible.

In chapters two and three, Longo constructs a history tracing technical communication practices from their origins (she claims) in the field of mining engineering. She points to T.A. Rickard, a miner turned technical writer, editor and text book producer as the first modern technical communicator, and summarizes his position that technical language translates scientific knowledge into a coinage that engineers should contribute to the general fund of scientific knowledge. She then outlines the sources of Rickard's position by providing a parallel history of the development of public science and the role that textbooks played in the emergence of technical education practices. Her academic history begins with Francis Bacon, includes John Locke and concludes with Thomas Huxley who was, in fact, Rickard's mentor and teacher. The history of opposition to scholasticism and the development of attitudes espousing 'clear' language are well documented within other published literature.

However, Longo's parallel history of the contributions of textbooks to technical education provides a new contribution to research and makes for fascinating reading. Her narrative begins with the encylopedic and Hermetic traditions of ancient Greece, especially those associated with the secrets of mining. However, she asserts that this tradition changed radically in the seventeenth century when Johann Amos Comenius, under the influence of Francis Bacon, began publishing sequenced, organized accounts of technical practices. Longo explains that, from the outset, these textbooks participated in asserting ideological positions. During the seventeenth century, textbooks took up Bacon's position that scientific knowledge was a public rather that a private enterprise. One of the immediate effects of Comenius' sequenced textbooks was that the text, not the teacher, became the focus of authority. As a result, teaching practices became more standardized throughout the eighteenth century.

In chapter five Longo continues exploring the parallel histories of influential historical figures and their intersections with textbook traditions. In this chapter she outlines the central role played by the "grandfather" of technical communication, T.A. Rickard, in terms of developing the field in North America at the turn of the twentieth century. For Rickard, technical writers were engineers and were charged with the responsibility of keeping technical language pure and unsullied so that they could convey accurately the truths of science and technology. Longo asserts that 
Rickard laid down the foundational beliefs of the field: the need for plain, pure language to provide a conduit for scientific and technical information to reach wider publics; and the belief that meaning exists outside of language. At the same time Longo notes that, after Rickard, virtually all technical communication textbooks of the twentieth century begin with an "apologia" or defence of the need for learning technical communication. Most of these introductory arguments urged their readers to perfect their communication skills in order to increase their personal chances of success in the workplace. In fact, most textbooks written before and right after the second world war presumed that their male readers were learning writing skills as a secondary "add on" to their real careers as scientists and engineers. In effect, textbooks contributed to the widening gap between content experts and language experts, a direct result perhaps of the conduit metaphor that characterized Rickard's view of technical communication.

In the next two chapters Longo provides a fascinating account of the relationship between engineering and management and more explanations for the tensions that exist between engineers and technical communication experts. Longo points out that scientific management systems such as Frederick Taylor's, emerged out of engineers' need to manage large scale projects (building railroads, bridges) and explicitly exploited military models of efficiency. The military model established hierarchies within the workplace supported by reporting structures. Just as in an army orders from a general proceed down through a chain of command to the private soldiers and reports on activities flow back to the general, so too in the workplace orders from management proceed down to the workers and reports on their activities flow back to management. This model of management depends, of course, on highly literate writing practices, i.e. technical communication, to maintain it.

Technological advances also contributed to the development of scientific management and related discourse practices. The advent of the calculator and most importantly the typewriter ensured even more specialization and the deskilling of clerical workers. Traditionally the clerical staff had composed and written much of the correspondence and records. Typewriters and the hiring of stenographers meant a division of labour so that higher paid managers could focus on managing and composing while lower paid, mostly women, clerical workers generated the actual documents. As Longo, quoting JoAnne Yates, also points out, specific genres such as the memo, developed as a result of this intersection of technology and management practices.

During the early part of the twentieth century textbooks emerged that reflected this intersection of technology, scientific management, and discourse practices. Technical communication textbooks began to focus on teaching male managers how to 
interact with their mostly female staff. One result was that a whole new field of communication-business communication-developed. Another result was that technical communication, especially the teaching of technical communication, began moving away from the control of engineers and scientists towards specialists in English Departments. Consequently, after the second world war, a new group of technical communicators developed-language specialists who were not engineers or scientists. This division of labour suited the hierarchical nature of workplaces during this period as it allowed higher paid content experts more time to develop their products, while the work of explaining those products fell to lower paid technical communicators. The end result, from Longo's perspective, was a devaluation (hence the title of her book Spurious Coin) of technical communication. As Longo notes, the role of the technical communication specialist is not just the result of "common sense." Rather a whole history of tensions lies behind current practices.

In her last chapter, Longo tries to argue for an acceptance of this history and a future orientation that would celebrate technical communications' roots in both the humanities and the sciences. She argues that critical histories such as hers together with empirical research traditions can lead to critical technical communicators, communicators who could question some of the destructive networks of discursive power within organizations. She wants, in other words, "humanistic technical writing." These sets of practices could conceivably be pursued by both content and language specialists. However, these practices, Longo asserts, will not be found in textbooks, but rather in our journals, scholarly books and debates within the discipline.

In many ways Longo's book is an impressive achievement. She weaves together a detailed, critical history of technical communication that spans from the classical period to the present. More importantly her work is truly critical. She examines critically the origins of beliefs in transparent language and the consequences of the subject position occupied by technical communicators. Sometimes, however, Longo seems to be claiming too much for the field. For example, several times during her history, she asserts that technical communication existed during the seventeenth and eighteenth century and was "the instrument for minting this currency of scientific knowledge" ( p.54). Perhaps some stylistic traditions existed during this period that latter technical communicators profited from, but it seems like an overstatement to claim that technical communication as a field existed during these periods. I also found Longo's last chapter on the future of technical communication a little too optimistic given the power of her argument in previous chapters.

In general, however, I recommend Spurious Coin. Longo provides a fascinating historical context for central debates in our field. 